\title{
THE ARENÓPOLIS-MARA ROSA GOLD-COPPER BELT, NEOPROTEROZOIC GOIÁS MAGMATIC ARC
}

\section{CLAUDINEI GOUVEIA DE OLIVEIRA ${ }^{1}$, CLÁUDIA LIMA DE QUEIROZ ${ }^{1}$ AND MÁRCIO MARTINS PIMENTEL ${ }^{1}$}

\begin{abstract}
The Goiás Magmatic Arc hosts several gold and copper-gold deposits, which were originated during several stages of the tectonic, magmatic and metamorphic evolution of this Neoproterozoic Arc, between $c a$. 0.9 and $0.6 \mathrm{Ga}$. The nature of these deposits, their spatial distribution, and timing of mineralization agree with the model involving the continuous evolution of a collisional belt. They also display some of the characteristics of the orogenic gold deposits. The Zacarias Au-Ag-Ba Deposit was originated by volcano-exhalative processes in an intraoceanic subduction setting, whereas the Chapada $\mathrm{Cu}$-Au Deposit (porphyry copper-type mineralization) is connected with plutonic rocks also associated with an intra-oceanic arc. The Posse Au Deposit was formed during the syn-collisional phase, shortly following the metamorphic peak of the Brasiliano Orogeny ( $\mathrm{ca}$. $630 \mathrm{Ma}$ ). Finally, the genesis of the Mundinho Au-Cu-Bi Mineralization is related with the emplacement of granite intrusions associated with post-orogenic extension.
\end{abstract}

Keywords: Goiás magmatic arc, gold and copper-gold mineralization, orogenic evolution.

INTRODUCTION Recently, Groves et al. (1998) introduced the term orogenic gold deposits, as a substitute for the so-called mesothermal gold deposits. According to the original definition of Lidgreen (1933 in Groves et al. 1998), the term mesothermal refers only to ore deposits formed at depths between 1.2 to $3.6 \mathrm{~km}$. Such depth range, however, does not include the majority of gold deposits classified as mesothermal, in which pressure varies between 1 and 3 kbar and temperature ranges from 300 to $400^{\circ} \mathrm{C}$.

Orogenic gold deposits are classified according to their depths of formation as: (i) epizonal $\left(<6 \mathrm{~km}, 150-300^{\circ} \mathrm{C}\right)$, (ii) mesozonal $(6-12$ $\left.\mathrm{km}, 300-475^{\circ} \mathrm{C}\right)$ and (iii) hypozonal $\left(>12 \mathrm{~km},>475^{\circ} \mathrm{C}\right)$. The term "orogenic deposits" also carries a tectonic significance, since most of the deposits are formed in compressive and transpressive environments, within convergent plate margins during collisional and accretionary orogeny (Groves et al. 1998).

In the central part of Brazil, the Neoproterozoic Goiás Magmatic Arc, a large segment of 900-650 Ma juvenile crust, hosts several gold and copper-gold deposits, which are herein included in the so-called Arenópolis-Mara Rosa gold-copper belt. The aim of this paper is to review the main features of these deposits and to discuss models for their origin and evolution. Some of them are characterized as typical orogenic gold deposits.

THE GOIÁS MAGMATIC ARC The Tocantins Structural Province corresponds to a large Neoproterozoic (Brasiliano/PanAfrican) orogenic zone developed between two major continental blocks: The Amazon Craton in the west; and the São Francisco Craton in the east (Fig. 1). The eastern part of the Province is occupied by the Brasília Belt, which includes mainly a thick metasedimentary sequence and a large area where juvenile Neoproterozoic arc rocks are exposed (The Goiás Magmatic Arc). Within the Tocantins Structural Province, the most pervasive group of structures shows mass transport towards the São Francisco Craton. This pattern is interpreted as the most conspicuous features of the Neoproterozoic deformation, during the Brasiliano Cycle (Fuck et al.1994).

The Arenópolis-Mara Rosa gold-copper belt is located in the Goiás Magmatic Arc, which extends for more than $400 \mathrm{~km}$ the western and northern parts of the Goiás State (Fig. 1). Two main areas of Neoproterozoic juvenile crust have been identified. These are hereafter referred to as the Arenópolis and Mara Rosa Arcs, respectively in the southern and northern ends of the arc (Pimentel et al. 1991, 1997). The Mara Rosa Arc is the focus of this paper because it contains the majority of deposits.

GEOLOGY AND GEOCHRONOLOGY The Goiás Magmatic Arc is made largely of tonalitic/dioritic orthogneisses, which underlie large areas between narrow N20-30E volcano-sedimentary sequences. In the Chapada-Mara Rosa Area, these supracrustal rocks form three individual NNE belts, known as the eastern, central and western belts, separated from each other by metatonalites/metadiorites. These belts are made of metabasalts, intermediate and felsic metatuffs, fine-grained metagraywackes, garnet mica schists, metacherts, iron formations, quartzites and metaultramafic rocks, metamorphosed in the

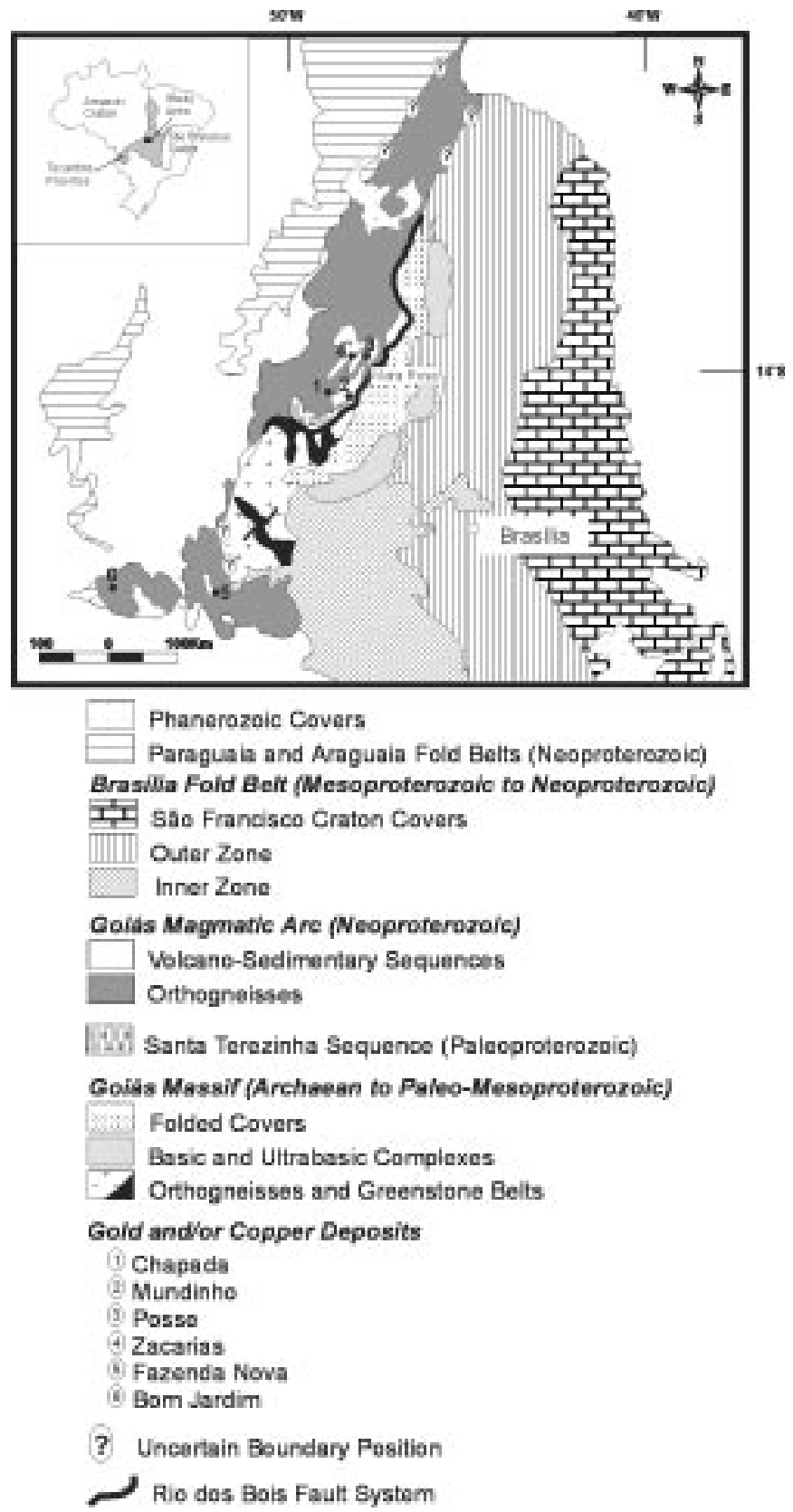

Figure 1-Regional geologic map of the Northern Sector of the Tocantins Province, in Central Brazil (after Fuck et al. 1994). 
greenschist- to amphibolite-facies conditions (Arantes et al. 1991). Uranium-lead zircon data for small elongated bodies of mylonitic granites this felsic rock in the Posse Gold Mine yield a crystallization age of $862 \pm 8 \mathrm{Ma}$. Titanites from the same sample yield a metamorphic age of $632 \pm 4 \mathrm{Ma}$ (Pimentel et al. 1997).

Amphibolites of the volcano-sedimentary sequence are either tholeiitic, rich in $\mathrm{Mg}, \mathrm{Ni}$ and $\mathrm{Cr}$ and similar to boninites, or calcalkaline. According to Palermo (1998), the former could represent fragments of oceanic crust and the latter are related to the arc magmatism. In the Chapada Area, garnet and epidote amphibolites are chemically similar to modern-arc tholeiites and are interpreted as being originated in a back-arc setting (Kuyumjian 1989).

Metasedimentary rocks represented by feldspathic garnet mica schists and fine-grained biotite gneisses are abundant in the supracrustal belts, especially in the western belt. Samariumneodymium isotopes for these rocks indicate $\mathrm{T}_{\mathrm{DM}}$ values dominantly in the range $0.9-1.2 \mathrm{Ga}$, with only one analysis y1elding a significantly older model age of $1.6 \mathrm{Ga}$. This indicates that they are the products of erosion of the arc rocks, with little contribution from older sources. The deposition of the original sediments must have taken place far from any old continental source area and probably happened in an intra-oceanic setting. Samarium-neodymium garnet-whole rock isochrons for these metasedimentary rocks indicate ages of $c a$. 733 , 765, 604 and $610 \mathrm{Ma}$. These were interpreted as resulting from two metamorphic episodes: an early one at $c a$. $760 \mathrm{Ma}$ and a later metamorphic event with typical Brasiliano ages (ca. $600 \mathrm{Ma})$.

In the Chapada-Mara Rosa Area, the medium- to coarse-grained, grey metaplutonic rocks of dioritic to tonalitic compositions, locally show well preserved plutonic textures such as enclaves and porphyritic textures. They are geochemically very primitive with $\mathrm{SiO}_{2}$ contents of less than $60 \%$, with a calcic to calc-alkaline character, characterized by low $\mathrm{Rb}, \mathrm{Nb}, \mathrm{Y}, \mathrm{Zr}$ and REE. They are similar to M-type granitoids of immature island arcs (Pimentel et al. 1997). Uranium-lead zircon data indicate crystallization of the protolith at $856 \pm 13 \mathrm{Ma}$. Neodymium isotopic data indicate the very primitive nature of the original magma, with $\mathrm{T}_{\mathrm{DM}}$ values of $c a$. $0.9-1.0 \mathrm{Ga}$ and $\varepsilon_{\mathrm{Nd}}(\mathrm{T})$ of +4.6 . The last deformational event affecting the Mara Rosa rocks at $c a$. $600 \mathrm{Ma}$ was immediately followed by the intrusion of several granitic intrusions (e.g. the Faina, Angelim, Estrela and Amador granites) as wells as gabbro-dioritic bodies. The granite bodies include mainly biotite granites and two-mica leucogranites, with local granodioritic facies (Pimentel et al. 1997). The mafic intrusions are made of diorites and, to a lesser extent, gabbros, and very commonly display magma mixing structures.

Similarly to the Arenópolis Area, the Precambrian geological evolution of the Mara Rosa arc ended, therefore, with an important bimodal magmatic event. In both cases this is interpreted to be associated with final uplift and collapse of the Brasiliano Orogen.

The bimodal nature of this magmatism suggests that the input of heat required to promote large-scale melting of the crust was most probably provided by the emplacement and/or underplating of mafic magma into the continental crust. This abundant post-Brasiliano granitic magmatism is spatially confined to the regions underlain by the juvenile arc rocks. This suggests that these were preferable sites of uplift and melting of the mantle and continental crust or, alternatively, that the juvenile crust behaved as a more "fertile" material for granite production. Field and geochronological evidence suggest that the emplacement of these bodies occurred under extension, which accompanied rapid uplift and unroofing of the region. Amphibolite facies metavolcanic rocks with $\mathrm{U}-\mathrm{Pb}$ titanite ages of $c a .590 \mathrm{Ma}$ are intruded by $c a$. $560 \mathrm{Ma}$ sub-volcanic microgranite dikes.

\section{NEOPROTEROZOIC DEFORMATION IN CENTRAL}

BRAZIL The Brasiliano structures can be grouped into two deformational phases, $D_{n}$ and $D_{n+1}$. During $D_{n}$, southeast-verging, tangential structures were generated. These encompass tangential shear zones and thrust faults, always accompanied by tight to isoclinal folds (NE to NW axis), locally a-folds, and a conspicuous NW stretching lineation. These structural features were rotated during $\mathrm{D}_{\mathrm{n}+1}$ mainly into NW- and NE-directed structures. It also formed open to gentle folds (NS axes), a pair of synchronous crenulation cleavages (NS and EW axes) and two types of directional shear zones, of first and third orders. The first-order shear zones are oriented about N50W, have a sinistral character, and may be accompanied by N70E dextral shear zones, whereas the third-order shear zones are mainly NS-striking and dextral

In the Chapada-Mara Rosa Area, the most important structural feature is the Rio dos Bois Fault System (Fig. 1), which has been interpreted as a single fault, originated during the Brasiliano Cycle, with an oblique reverse dextral sense. However, geophysical images show that the NE trace of the Rio dos Bois System does not belong to the same structure of the north concave trace. The north concave trace separates the Archaean greenstone belts of Crixás Region from the Palaeoproterozoic Santa Terezinha Sequence, showing a general northward transport. The northeast trace separates the Santa Terezinha Sequence from the Chapada-Mara Rosa Neoproterozoic Sequence, and extends into the greenstone terrains, crosscutting them in an oblique dextral sense. Thus, the concave-to-the-north trace is interpreted as an ancient structure, due to the TransAmazonian Cycle (Palaeoproterozoic), whereas the northeast trace is interpreted as a Neoproterozoic structure. Also important in the Chapada-Mara Rosa Area are the NS-dextral shear zones, which may control some mineralizations.

GOLD AND GOLD-COPPER DEPOSITS The ArenópolisMara Rosa Region contains some important Au (Posse, Zacarias, Fazenda Nova) and Cu-Au (Chapada, Bom Jardim, Mundinho) deposits (Fig. 1). Mining companies have investigated the region since the beginning of the 1970's. During this period, investments in exploration were discontinued several times, due to gold price fluctuations in the international market.

Gold and gold-copper deposits of the Mara Rosa Belt occur in four main associations: i) Au-Ag-Ba (e.g. Zacarias Deposit), which is interpreted as a stratiform volcanogenic-type deposit (Poll 1994); ii) $\mathrm{Cu}-\mathrm{Au}$ (e.g. Chapada Deposit), which has been interpreted either as volcanogenic- (Kuyumjian 1989), or as a porphyry-type deposit (Richardson 1988); iii) Au-only deposit (e.g. Posse Deposit), which has been interpreted as epigenetic disseminated deposit controlled by a mesozonal shear zone (Palermo 1998); and iv) Au-Cu-Bi (e.g. Mundinho deposit), which are considered as vein-type deposits controlled by magnetite-rich diorites.

The Zacarias orebody, characterized by the gold-silver-barite association, is concordant with the host amphibolites of probable volcanoclastic origin. The ore zone consists of concordant lenses of quartz, barite, barium-muscovite (oellacherite), pyrite, and minor sphalerite, galena, chalcopyrite, zincian spinel, magnetite, electrum, freibergite and boulangerite, with subordinate tetrahedrite/bournonite. Molybdenite and covellite are also present in very small amounts (Poll 1994). Gold content is proportional to barite content. Gold concentration in barite quartzites varies from 3.0 to $15.0 \mathrm{~g} / \mathrm{t}$, while oellacherite quartzites contain generally less than $3.0 \mathrm{~g} \mathrm{Au} / \mathrm{t}$ (Poll 1994).

The Chapada copper-gold deposit consists of a disseminated pyritechalcopyrite-magnetite mineralization, hosted by feldspathic quartzites and biotite-rich schists of probable tuffaceous origin. Bornite, chalcosite, sphalerite, galena, pyrrothite and molybdenite are subordinate. Sulfides are deformed, indicating a pre-metamorphic origin of the deposit. Gold occurs in chalcopyrite or between sulfide grains. The geological resource stands at $30 \mathrm{Mt}$ of oxidized ore, grading $0,6 \mathrm{~g} / \mathrm{t}$ gold and $c a .200 \mathrm{Mt}$ sulfide ore zone grading $0.4 \mathrm{~g} \mathrm{Au} /$ $\mathrm{t}$ and $0,43 \% \mathrm{Cu}$.

The Posse Gold Deposit is hosted by microcline gneisses derived from felsic rocks. Basic metavolcanic rocks occur at the footwall sequence and locally host mineralization. Hydrothermal alteration is intense and affects both the hangingwall and the footwall sequences. An outer alteration halo is composed by a propylitic assemblage, composed of epidote-pyrite-sericite. The inner zone is represented by strong silicification with abundant associated sulfide (pyrite). Gold occurs mainly as native grains, but also associated with tellurides (frohbergite and calaverite). Gold mineralization is controlled by a series of parallel lenses trending $\mathrm{N} 20^{\circ}-30^{\circ} \mathrm{E} / 50^{\circ} \mathrm{NE}$ and plunging $35^{\circ}$ $45^{\circ} \mathrm{SW}$. The deposit has a maximum length of $1 \mathrm{~km}$ and is 300 -meters wide in the southern portion and 400 meters wide in its northern portion. The gold reserve is $1.7 \mathrm{Mt}$ grading $2.24 \mathrm{~g} / \mathrm{t}$ (down to 60 meters) (Arantes et al. 1991).

The occurrences controlled by the NS-transcurrent system are veins or quartz segregations containing quartz, sulfides (pyrite, chalcopyrite, bismutinite), magnetite and ilmenite. The veins are hosted in granites 
(e.g. Mundinho deposit ) and magnetite-rich diorites (Suruca occurrence), which include an association of wall rocks represented by magnetite quartzites and magnetite-pyrite-muscovite-quartz schists.

\section{GOLD MINERALIZATION AND HYDROTHERMAL} ALTERATION Hydrothermal mineral parageneses have been described in several of the gold-copper mineralizations of ChapadaMara Rosa Region. The necessity of working with metamorphosed and deformed products, with no evidence of a neat zoning of the halos of hydrothermal alteration, led Richardson (1986) and Kuyumjian (1989) to distinct propositions about the genetic model involved in the generation of the hydrothermal associations in the Chapada deposit.

Kuyumjian $(1989,1991)$ gives special attention to the alteration zones that occur adjacent to the mineralization in the Chapada deposit. The author suggests that epidote-rich and epidosite zones result from intensive, high-temperature interaction of sea water with basaltic rocks prior to the tectonic event responsible for the penetrative schistosity in the Chapada rocks. The epidosites may represent the feeder system through which hydrothermal solutions moved to form the ore deposits. The magnetite pyritic quartz sericite schists, also very common in the Chapada-Mara Rosa Region, could represent a metamorphosed phyllic alteration zone formed as a result of the metasomatism imposed by hydrothermal solutions. The author also emphasizes that the presence of a staurolite-gedrite rock closely associated with the mineralization in the Chapada deposit may represent the metamorphosed chloritic alteration zone, while the presence of microcline-bearing schists, rich in $\mathrm{K}_{2} \mathrm{O}$, suggest that potassic alteration occurred during the formation of the copper-gold mineralization in Chapada.

On the other hand, Richardson (1986) combines geologic and geochemical hydrothermal alteration evidences rather than mineralogical to suggest that the Chapada deposit represents the remains of a porphyry copper deposit of island-arc setting, in which most of the mineralization was hosted by wall rock. The evidence comprise: an intensely disseminated distribution of the copper and gold and the absence of massive sulfide lens; the grade, tonnage and gold values, perfectly compatible with those of island-arc porphyry copper deposits; the sulfide and oxide minerals at Chapada, as well as their zonations, including the peripheral pyritic shell and the central magnetite-rich zone, are the same as those commonly seen in porphyry copper deposits; the magmatic affiliation deduced from the $\mathrm{S}$ isotope composition (zero per mil); the chemistry of the alteration around the deposits is also similar to that seen in porphyry copper deposits, with enrichment in $\mathrm{K}_{2} \mathrm{O}$ and depletion in $\mathrm{Na}_{2} \mathrm{O}$ and $\mathrm{CaO}$.

The studies in the Posse Deposit are also controversial, not only regarding the genesis of the mineralization but also the nature of the wallrock. For Arantes et al. (1991), the microcline gneisses that host the deposit represent metamorphic products of acid volcanic rocks previously altered by the circulation of aqueous solutions. The genesis of the mineralization might have been connected with this volcanoexhalative interaction. On the other hand, Palermo (1998) interprets the microcline gneisses as original alkaline granitic intrusions, with evidence of hydrothermal alteration (sericitization, albitization), which resembles those which follow the process of greisenization. The main event of gold mineralization, however, is not would not be connected with this late-magmatic episode, but with a later event after the peak of metamorphism and deformation event. Gold mineralization is controlled by halos of propilitization, albitization, sericitization, silicification, carbonation and deposition of oxides (magnetite, \pm ilmenite), sulfides (pyrite \pm chalcopyrite \pm pyrrhotite) and tellurides ( $\mathrm{Au}, \mathrm{Ag}, \mathrm{Bi}, \mathrm{Pb}, \mathrm{Fe})$.

Ideas concerning the genesis of the Zacarias deposit converge to a consensus. This deposit, with lenticular geometry and hosted by basic metavolcanic rocks and chemical metasedimentary rocks, is constituted by different kinds of sulfide- and barite-rich rocks generated in a proximal volcano-exhalative environment. Hydrothermal alteration products are represented by aluminous, quartz-biotite schists, probably a product of metamorphism of clay-sericite-rich debris derived from hydrothermal vents. Other minor mineral alteration products include talc, chlorite, epidote, sericite, quartz, K-feldspar and calcite (Poll 1994).

Similarly to the gold deposits hosted by the hydrothermally altered granitic mylonites (Mundinho deposit), there is no direct relation between the hydrothermally altered wallrock (epidote-rich rocks to epidosites and magnetite-pyrite-quartz-muscovite schists) and the mineralized rocks. In this case, the halos of potassic alteration which accompanied the mineralization were controlled by transcurrent-NS deformation, which clearly post-date the alterations which previously affected the wallrock.

DISCUSSION AND CONCLUSIONS The gold and coppergold deposits, located within the Goiás Magmatic Arc, can be temporally and spatially related to the magmatic evolution model of a collisional belt proposed by Harris et al. (1986), as well as to the orogenic gold deposits model postulated by Groves et al. (1998). These models are based on a continuous evolution of collisional plates, which can be divided into four stages with distinct magmatic characteristics: i) subduction stage; ii) syn-tectonic collisional magmatism stage; iii) post-tectonic collisional magmatism stage; and iv) post-orogenic extension stage.

In the Tocantins Province the first stage, intra-oceanic subduction, probably occurred between 0.8 and $0.9 \mathrm{Ga}$ and is represented by tholeiitic volcanic rocks and calc-alkaline plutonics (M- and I-type granitoids) of island arcs and back-arc basins. During this stage the deposits of Zacarias (Au-Ag-Ba), Chapada $(\mathrm{Cu}-\mathrm{Au})$ and Bom Jardim $(\mathrm{Cu}-\mathrm{Au})$ were formed. The Zacarias deposit was generated due to proximal volcano-exhalative brines (Poll 1994), whereas the Chapada and Bom Jardim deposits are probably related to porphyritic coppergold genesis.

Subsequent to this stage was syn-tectonic collisional stage, leading to a maximum crustal thickening in the area, which is related to a metamorphic peak of $c a$. $630 \mathrm{Ma}$ at the end of the Brasiliano orogeny. During this period, the northeast arm of the Rio dos Bois Fault System evolved and controlled many gold occurrences in the region, including the Posse deposit $(\mathrm{Au})$. The latter represents a mesozonal shear zonecontrolled gold deposit (Palermo 1998), or the so-called orogenic gold deposit. The fluid migration in these shear zones might have started at $760 \mathrm{Ma}$. This age is interpreted as another metamorphic peak, related to a poorly known event that occurred during an accretionary stage between oceanic and continental plates.

The post-tectonic collisional magmatism, and the post-orogenic extension, succeeded the maximum crustal thickening peak. This is marked by the intrusion of alkaline granitic bodies (mainly biotite granites and leucogranites), and magnetite bearing gabbro-dioritic bodies between 590 and $560 \mathrm{Ma}$. The $\mathrm{Au}-\mathrm{Cu}-\mathrm{Bi}$ Mineralization (Mundinho deposit), controlled by the magnetite bearing gabbrodioritic intrusions, occurs as disseminated ore associated to the intrusions and/or veins. The veins are related to NS transcurrent shear zones $\left(\mathrm{D}_{\mathrm{it}}\right.$ Phase) that crosscut the Rio dos Bois System.

The evolution of the Goiás Magmatic Arc provided many distinct geotectonic environments, such as oceanic arc, back arc basin, and accreted terrains. These environments are favorable to gold and copper-gold deposit formation because of their depth, magmatic association and structural framework. The deposits here described and other small occurrences confirm this interpretation.

\section{References}

Arantes D., Buck P.S., Osborne G.A., Porto C.G. 1991. A Sequência Vulcano-Sedimenta de Mara Rosa e Mineralizaç̃es Auríferas Associadas. Boletim Informativo da SBG, Núcleo Centro-Oeste, 27-40.

Fuck R.A. 1994. A Faixa Brasília e a Compartimentação Tectônica da Província Tocantins. In: SBG. Simpósio de Geologia do Centro-Oeste, 4 Brasília. Anais 1:184-187.

Groves D.I., Goldfarb R.J., Gebre-Mariam M., Hagemann S.G., Robert F. 1998. Orogenic gold deposit: A proposed classification in the context of their crustal distribuition and gold deposit: A proposed classification in the context of their crustal distribuition

Harris N.B.W., Pearce J.A., Tindle A.G. 1986. Geochemical characteristics of collision-zone magmatism. In: M.P. Coward, A.C. Ries (eds). Collision Tectonics, London, Geological Society Special Publication, 19:67-81.

Kuyumjian R.M. 1989. The geochemistry and tectonic significance of amphibolites from the Chapada sequence, Central Brazil., Imperial College, England, PhD. Thesis, 289 $\mathrm{p}$.

Palermo N. 1998. Le gisement aurifère précambrien de Posse (Goiás, Brésil) dans sons cadre géologique. ENSMP, Paris, These de doctorat. 175 p.
Pimentel M.M., Heaman L., Fuck R.A. 1991. U-Pb zircon and sphene geochronology of late Proterozoic volcanic arc rock units from southwestern Goiás, central Brazil. Journal of South American Earth Sciences, 4:329-339.

Pimentel M.M., Whitehouse M.J., Viana M.G., Fuck R.A., Machado N. 1997. The Mara Rosa arc in the Tocantins Province: further evidence for Neoproterozoic crustal accretion in central Brazil. Precambrian Research, 81:299-310.

Poll N.J.1994. The geology of the Zacarias gold-silver-barite deposit, Goiás State, Brazil Colorado School of Mines, USA, Master thesis, 124p.

Richardson C.J., Kesler S.E., Essene, E.J. 1986. Origin and geochemistry of the chapada $\mathrm{Cu}$-Au deposit, Goiás, Brazil: a metamorphosed wall-rock porphyry copper deposit. Economic Geology, 81:1884-1898. 